\title{
2019Spring PaduaMuscleDays: Translational Myology and Mobility Medicine
}

\author{
Ugo Carraro $(1,2)$
}

(1) Interdepartmental Research Centre of Myology (CIR-Myo), Department of Biomedical Sciences, University of Padova, Italy; (2) A\&C M-C Foundation for Translational Myology, Padova, Italy

This article is distributed under the terms of the Creative Commons Attribution Noncommercial License (CC BY-NC 4.0) which permits any noncommercial use, distribution, and reproduction in any medium, provided the original author(s) and source are credited.

\begin{abstract}
A half-century tradition of skeletal muscles studies, started with a research on fever, is continuing under the auspices of the Interdepartmental Research Centre of Myology (CIR-Myo), Department of Biomedical Sciences, University of Padova, Italy, the A\&C M-C Foundation for Translational Myology, Padova, Italy and the European Journal of Translational Myology (EJTM). This year an EJTM Special will be dedicated to Muscle Fascia, an under looked topic, which merits more attention. Furthermore, this year the 2019SpringPaduaMuscleDays: Translational Myology and Mobility Medicine, an International Conference, was held March 2830, 2019 in Euganei Hills and Padova (Italy). The abstracts of the 2019SpPMD, that are reported in the Myology News of EJTM 29 (1), 2019, are excellent examples of translational research. Their excellent contents are at the level needed for approval by Ethical Committees, International Granting Agencies, and Editors of international journals, thanks to the high scientific profiles of researchers and clinicians who are eager to present their results at the PaduaMuscleDays.
\end{abstract}

Key Words: PaduaMuscleDays, Translational Myology and Mobility Medicine

Eur J Transl Myol 29 (1): 41-45, 2019

Myologists working in Padua (Italy) were able to continue a tradition of skeletal muscle studies started half century ago with a research project whose aim was to explain if skeletal muscle is responsible of fever by burning bacterial toxins. ${ }^{1}$ This concept sounds strange, but recent results on effects of myokines may attract new researchers. $^{2}$ Part of that tradition developed in the institution of the Interdepartmental Research Center of Myology of the University of Padova (CIR-Myo), in the organization of the PaduaMuscleDays (PMD), a series of International Conferences organized in Euganei Hills (Padova), Italy and in the publication of Basic and Applied Myology (BAM) (retitled from 2010 European Journal of Translational Myology - EJTM). This year an Ejtm Special Edited by Carla Stecco and Raffaele De Caro will be dedicated to Muscle Fascia, an under looked topic that merits more attention. For many years the fasciae have been considered by anatomists only as a "white envelope for the muscles", that is generally removed in anatomical tables, to recognize muscle nerves and vessels. This is one of the reasons that different descriptions of the fasciae exist. On the other hand, in the last years the fasciae and their properties are becoming of central importance to clinicians practicing in various conventional and alternative therapies. The results from the worldwide research activities constitute a body of significant and important data, but this clinical interest is not supported by in-depth comprehension to how integrate the new knowledge about fasciae with the classical biomechanical models based on muscles, tendons and bones. To close this gap an Ejtm Special on "Muscle Fascia" will be published September 30, 2019. The aim of the "2019 Ejtm Special on Muscle Fascia" is to point attention to several open questions: Do fasciae have a role in pain perception? How fasciae and muscles interact during movement? Have the fascia a role in posture? How do the various fasciae appear under ultrasound, MRI, and CAT scans? Could these instruments help us to understand the structure of the fasciae in living people? What is the role of the extracellular matrix, and in particular of the hyaluronic acid component? What is the percentage of elastic fibres within fasciae? Are there regional variations? Are fasciae innervated, playing a role in proprioception? Have they the capacity to actively contract? Do fasciae have a role in motor coordination? ${ }^{3-23}$ Answers to these questions 

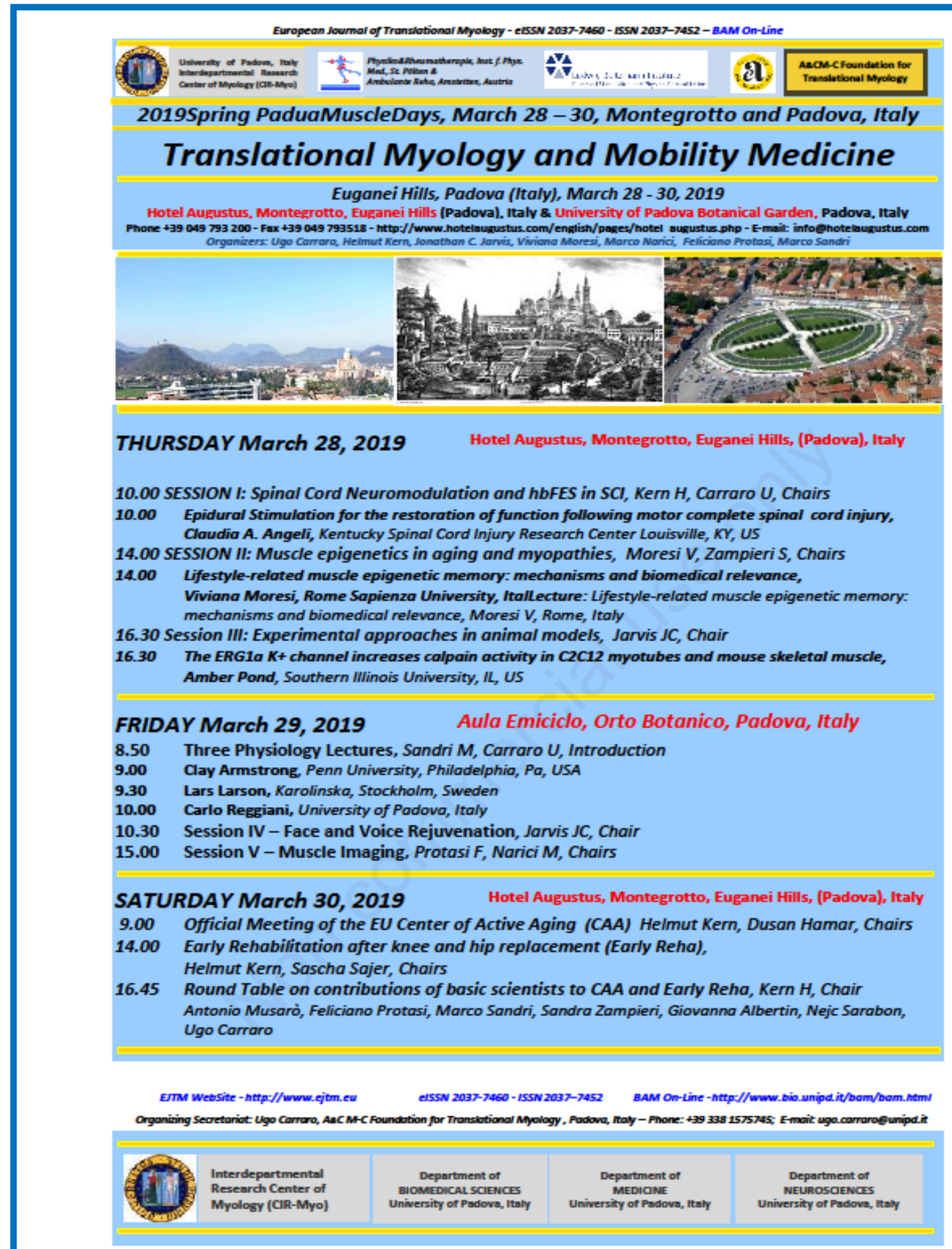

Fig. 1. Leaflet of the 2019SpringPaduaMuscleDays

will add to the many tools of rehabilitation strategies, contributing to understanding the biomechanical behavior of the fasciae, of their role in myofascial pain syndromes and of the effectiveness of different therapies. This year the 2019Spring PaduaMuscleDays were once again held in Euganei Hills and Padova March 28-30 under the sub title of Translational Myology and Mobility Medicine. The backbone of the 2019SpPMD program is presented in Figure 1. The cryptic subtitle (Translational Myology and Mobility Medicine), may have attracted not 
only the core group of researchers that gathered year after year to Padova, but some new speakers that filled the sessions of the 3-day Program. As to the concept of Mobility Medicine, it is worth stressing that Mobility can be a Medicine, but also that in too many diseases there is impaired mobility that influence the patients' quality of life. The Thursday March 28, morning Session I (Spinal Cord Neuromodulation and hbFES in SCI, Kern H, Carraro U, Chairs) was opened by Claudia A. Angeli, Kentucky Spinal Cord Injury Research Center Louisville, KY, USA, who presented "Epidural Stimulation for the restoration of function following motor complete spinal cord injury", a new exciting development for thoraciclevel SCI patients. ${ }^{23}$ The Thursday March 28 afternoon Session II (Muscle epigenetics in aging and myopathies, Moresi V, Zampieri S, Chairs) saw Viviana Moresi as the first speaker, presenting "Lifestyle-related muscle epigenetic memory: mechanisms and biomedical relevance". The Thursday March 28 afternoon Session III (Experimental approaches in animal models, Jarvis JC and Mayr W, Chairs) was opened by the presentation "The ERG1a $\mathrm{K}^{+}$channel increases calpain activity in C2C12 myotubes and mouse skeletal muscle" by Amber Pond, Southern Illinois University, IL, USA. On Friday March 29, 2019 the second 2019SpPMD was held in the Aula Emiciclo, of the Orto Botanico, of the Padova University. Three Physiology Lectures, introduced by Marco Sandri, by Clay Armstrong, Penn University, Philadelphia, Pa, USA, Lars Larson, Karolinska, Stockholm, Sweden and Carlo Reggiani, University of Padova, Italy opened the Morning sessions. Whatever the names of physiology sub-specialization these speakers represented, they showed that quantitative evaluations of dynamic events of contraction machineries (action potential, E-C coupling, contractile proteins and energy metabolism of muscle fibers) are prerequisites of solid results in Myology and Mobility Medicine. Then, followed the morning and afternoon Sessions of Friday, March 29, Session IV (Face and Voice Rejuvenation, Jarvis JC, Chair) and Session V (Muscle Imaging, Protasi F, Narici M, Chairs). The afternoon of Friday March 29, 2019 ended with the guided visit of the Historical Botanical Garden of the University of Padova. Founded in 1545 by the Venetian Republic, it is the world's oldest academic botanical garden that is still in its original location. The garden is known for its special collections and historical design. It was devoted to the growth of medicinal plants, that produced natural remedies, and to teach students to recognize genuine medicinal plants. An after-dinner Guided Visit to Posters ended this very long PaduaMuscleDay. Saturday March 30, 2019 the meeting was held once again in the Conference Hall of Hotel Augustus, Euganei Hills, (Padova), Italy. The morning session was dedicated to the Official Meeting of the EU Center of Active Aging (CAA), Helmut Kern, Dusan Hamar, Chairs, while the afternoon was dedicated to the Session: Early Rehabilitation after knee and hip replacement (Early Reha), Helmut Kern, Sascha Sajer,
Chairs. A Round Table on contributions of basic scientists to CAA and Early Reha, Kern H, Chair, with Antonio Musarò, Feliciano Protasi, Marco Sandri, Sandra Zampieri, Giovanna Albertin, Andrea Porzionato, Nejc Sarabon and Ugo Carraro, closed the 2019Spring PaduaMuscleDays. As for the past PaduaMuscleDays, ${ }^{4-}$ 44 the abstracts of 2019SpPMD cover translational research involving physical, pharmacological and cellular strategies to maintain or recover structure and function of skeletal muscles, patients' mobility, to treat many medical diseases. The researches attained the high level needed to attract support by Granting Agencies and approval by Ethical Committees as well as by Editors of high impact journals. Many of the abstracts present, indeed, results mature to be translated into clinical applications. ${ }^{45}$ This happened in the past, ${ }^{46-48}$ it will happen in the future.

\section{Acknowledgments and Funding}

This typescript is sponsored by the $\mathrm{A} \& \mathrm{C}$ M-C Foundation for Translational Myology, Padova, Italy.

\section{Conflict of Interest}

The author declare to have none conflicts of interests.

\section{Ethical Publication Statement}

Author confirms that he have read the Journal's position on issues involved in ethical publication and affirms that this report is consistent with those guidelines.

\section{Corresponding Authors}

Ugo Carraro, Department of Biomedical Sciences, University of Padova, Italy.

E-mail: ugo.carraro@unipd.it

\section{References}

1. Carraro U. From BAM to BEM, a personal journey through EJTM and PaduaMuscleDays. Biol Eng Med 2017; 2(2): 1-2 doi: 10.15761/BEM.1000117.

2. Gabellini D, Musarò A. Report and Abstracts of the 14th Meeting of IIM, the Interuniversity Institute of Myology, - Assisi (Italy), October 12-15, 2017. Eur J Transl Myol 2017;27:185-224.

3. Schleip $R$ Jäger $H$, Klingler $W$. What is 'fascia'? A review of different terminologies. J Bodyw Mov Ther 2012;16:496-502. doi: 10.1016/j.jbmt.2012. 08.001. Epub 2012 Aug 22. Review.

4. Adstrum S. Fascial eponyms may help elucidate terminological and nomenclatural development. J Bodyw Mov Ther 2014;19:516-25. doi: 10.1016/j.jbmt.2015.04.002. Epub 2015 Apr 21.

5. Langevin HM, Fox JR, Koptiuch C, et al. Reduced thoracolumbar fascia shear strain in human chronic low back pain. BMC Musculoskelet Disord 2011;12:203. doi: 10.1186/1471-2474-12-203.

6. Taguchi T, Yasui M, Kubo A, et al. Nociception originating from the crural fascia in rats. Pain 
2013;154:1103-14. doi: 10.1016/j.pain.2013.03. 017.

7. Schilder A, Magerl W, Hoheisel U, et al. Electrical high-frequency stimulation of the human thoracolumbar fascia evokes long-term potentiation-like pain amplification. Pain 2016; 157:2309-17. doi: 10.1097/j.pain.000000000 0000649.

8. Wilke J, Schleip R, Yucesoy CA, Banzer W. Not merely a protective packing organ? A review of fascia and its force transmission capacity. J Appl Physiol 2018;124: 234-244. doi: 10.1152/jappl physiol.00565.2017. Epub 2017 Nov 9.

9. Carraro U, Edmunds KJ, Gargiulo P. 3D False Color Computed Tomography for Diagnosis and Follow-Up of Permanent Denervated Human Muscles Submitted to Home-Based Functional Electrical Stimulation. Eur J Transl Myol 2015 Mar 17;25(2):5133. doi: 10.4081/ejtm.2015.5133.

10. Edmunds $K$, Gíslason $M$, Sigurðsson $S$, et al. Advanced quantitative methods in correlating sarcopenic muscle degeneration with lower extremity function biometrics and comorbidities. PLoS One 2018;13:e0193241. doi: 10.1371/ journal.pone.0193241. eCollection 2018.

11. Vahed LK, Arianpur A, Gharedaghi M, Rezaei H. Ultrasound as a diagnostic tool in the investigation of patients with carpal tunnel syndrome. Eur J Transl Myol 2018 Apr 24;28(2):7380. doi: 10.4081/ejtm.2018.7406. eCollection 2018 Apr 24.

12. Fede C, Angelini A, Stern R, et al. Quantification of hyaluronan in human fasciae: variations with function and anatomical site. J Anat 2018;233:5526. doi: 10.1111/joa.12866. Epub 2018 Jul 24.

13. Benetazzo L, Bizzego A, De Caro $R$, et al. 3D reconstruction of the crural and thoracolumbar fasciae. Surg Radiol Anat 2011;33:855-62. doi: 10.1007/s00276-010-0757-7. Epub 2011 Jan 4.

14. Stecco C, Gagey $O$, Belloni A, et al. Anatomy of the deep fascia of the upper limb. Second part: study of innervation. Morphologie 2007;91:38-43.

15. Corey SM, Vizzard MA, Badger GJ, et al. Sensory innervation of the nonspecialized connective tissues in the low back of the rat. Cells Tissues Organs 2011;194,521-30.

16. Hoheisel $U$, Rosner J, Mense S. Innervation changes induced by inflammation of the rat lumbar fascia. Neuroscience 2015;300:351-59. doi: 10.10 16/j.neuroscience.2015.05.034. Epub 2015 May 21.

17. Lau WY, Blazevich AJ, Newton MJ, et al. Changes in electrical pain threshold of fascia and muscle after initial and secondary bouts of elbow flexor eccentric exercise. Eur J Appl Physiol 2015;115: 959-68. doi: 10.1007/s00421-014-3077-5. Ерub 2014 Dec 18.

18. Giuriati W, Ravara B, Porzionato A, et al. Muscle spindles of the rat sternomastoid muscle. Eur J
Transl Myol 2018;28:7904. doi: 10.4081/ejtm. 2018.7904. eCollection 2018 Nov 2.

19. Masiero S, Carraro U. (eds) Rehabilitation Medicine for Elderly Patients. Practical Issues in Geriatrics. Springer International Publishing AG, part of Springer Nature. doi: 10.1007/978-3-319. 57406-6_40.

20. Taylor MJ, Fornusek C, Ruys AJ. The duty cycle in Functional Electrical Stimulation research. Part II: Duty cycle multiplicity and domain reporting. Eur J Transl Myol 2018 Nov 7;28(4):7733. doi: 10.4081/ ejtm.2018.7733. eCollection 2018 Nov 2.

21. Taylor MJ, Fornusek C, Ruys AJ. Reporting for Duty: The duty cycle in Functional Electrical Stimulation research. Part I: Critical commentaries of the literature. Eur J Transl Myol 2018 Nov 7;28(4):7732. doi: 10.4081/ejtm.2018.7732. eCollection 2018 Nov 2

22. Laursen CB, Nielsen JF, Andersen OK, Spaich EG. Feasibility of Using Lokomat Combined with Functional Electrical Stimulation for the Rehabilitation of Foot Drop. Eur J Transl Myol 2016;26(3):6221. eCollection 2016 Jun 13.

23. Angeli CA, Boakye M, Morton RA, et al. Recovery of Over-Ground Walking after Chronic Motor Complete Spinal Cord Injury. N Engl J Med 2018; 379:1244-1250. doi: 10.1056/NEJMoa1803588.

24. Power GA, Dalton BH, Gilmore KJ, et al. Maintaining Motor Units into Old Age: Running the Final Common Pathway. Eur J Transl Myol 2017;27:6597. doi: 10.4081/ejtm.2017.6597. eCollection 2017 Feb 24.

25. Coletti D, Adamo S, Moresi V. Of Faeces and Sweat. How Much a Mouse is Willing to Run: Having a Hard Time Measuring Spontaneous Physical Activity in Different Mouse Sub-Strains. Eur J Transl Myol 2017;27:6483. doi: 10.4081/ejtm.2017.6483. eCollection 2017 Feb 24.

26. Pigna E, Greco E, Morozzi G, et al. Denervation does not Induce Muscle Atrophy Through Oxidative Stress. Eur J Transl Myol 2017;27:6406. doi: 10.4081/ejtm.2017.6406. eCollection 2017 Feb 24.

27. Coste CA, Mayr W, Bijak M, et al. FES in Europe and Beyond: Current Translational Research. Eur J Transl Myol. 2016;26:6369. doi: 10.4081/ejtm.2016.6369. eCollection 2016 Sep 15.

28. Scicchitano BM, Sica G, Musarò A.Stem Cells and Tissue Niche: Two Faces of the Same Coin of Muscle Regeneration. Eur J Transl Myol 201;26:6125. doi: 10.4081/ejtm.2016.6125. eCollection 2016 Sep 15.

29. Lavorato M, Gupta PK, Hopkins PM, FranziniArmstrong C. Skeletal Muscle Microalterations in Patients Carrying Malignant HyperthermiaRelated Mutations of the e-c Coupling Machinery. Eur J Transl Myol 2016;26:6105. doi: 10.4081/ejtm. 2016.6105. eCollection 2016 Sep 15. 
30. Carotenuto F, Coletti D, Di Nardo P, Teodori. L $\alpha$ Linolenic Acid Reduces TNF-Induced Apoptosis in C2C12 Myoblasts by Regulating Expression of Apoptotic Proteins. Eur J Transl Myol 2016;26:6033. doi: 10.4081/ejtm. 2016.6033. eCollection 2016 Sep 15.

31. Mosole S, Carraro U, Kern H, et al. Use it or Lose it: Tonic Activity of Slow Motoneurons Promotes Their Survival and Preferentially Increases Slow Fiber-Type Groupings in Muscles of Old Lifelong Recreational Sportsmen. Eur J Transl Myol 2016;26:5972. doi: 10.4081/ ejtm.2016.5972. eCollection 2016 Sep 15.

32. Edmunds KJ, Gíslason MK, Arnadottir ID, et al. Quantitative Computed Tomography and Image Analysis for Advanced Muscle Assessment. Eur J Transl Myol 2016;26:6015. doi: 10.4081/ejtm. 2016.6015. eCollection 2016 Jun 13.

33. Coletti D, Daou N, Hassani M, et al. Serum Response Factor in Muscle Tissues: From Development to Ageing. Eur J Transl Myol 2016;26:6008. doi: 10.4081/ejtm.2016. 6008. eCollection 2016 Jun 13.

34. Hiroux C, Vandoorne T, Koppo et al. Physical Activity Counteracts Tumor Cell Growth in Colon Carcinoma C26-Injected Muscles: An Interim Report. Eur J Transl Myol 2016;26:5958. doi: 10.4081/ejtm.2016.5958. eCollection 2016 Jun 13.

35. Tramonti C, Rossi B, Chisari C. Extensive Functional Evaluations to Monitor Aerobic Training in Becker Muscular Dystrophy: A Case Report. Eur J Transl Myol 2016;26:5873. doi: 10.4081/ejtm.2016.5873. eCollection 2016 Jun 13.

36. Riuzzi F, Beccafico S, Sorci G, Donato R. S100B protein in skeletal muscle regeneration: regulation of myoblast and macrophage functions. Eur J Transl Myol 2016;26:5830. doi: 10.4081/ejtm.2016.5830. eCollection 2016 Feb 23.

37. Barber L, Scicchitano BM, Musaro A. Molecular and Cellular Mechanisms of Muscle Aging and Sarcopenia and Effects of Electrical Stimulation in Seniors. Eur J Transl Myol 2015;25:231-6. doi: 10.4081/ejtm.2015.5227. eCollection 2015 Aug 24. Review.

38. Gabrielli E, Fulle S, Fanò-Illic G, Pietrangelo T. Analysis of Training Load and Competition During the PhD Course of a 3000-m Steeplechase Female Master Athlete: An Autobiography. Eur J Transl Myol 2015;25:5184. doi: 10.4081/ejtm.2015.5184. eCollection 2015 Sep 11.

39. Gargiulo P, Helgason T, Ramon C, et al. CT and MRI Assessment and Characterization Using Segmentation and 3D Modeling Techniques: Applications to Muscle, Bone and Brain. Eur J Transl Myol 2014;24:3298. doi: 10.4081/ejtm. 2014 3298. eCollection 2014 Mar 31.
40. Ortolan P, Zanato $R$, Coran A, et al. Role of Radiologic Imaging in Genetic and Acquired Neuromuscular Disorders. Eur J Transl Myol 2015;25:5014. doi: 10.4081/ejtm.2015.5014. eCollection 2015 Mar 11. Review.

41. Ravara B, Gobbo V, Carraro U, et al. Functional Electrical Stimulation as a Safe and Effective Treatment for Equine Epaxial Muscle Spasms: Clinical Evaluations and Histochemical Morphometry of Mitochondria in Muscle Biopsies. Eur J Transl Myol 201525:4910. doi: 10.4081/ejtm.2015.4910. eCollection 2015 Mar 11.

42. Franzini-Armstrong C. Electron Microscopy: From $2 D$ to $3 D$ Images with Special Reference to Muscle. Eur J Transl Myol 2015;25:4836. doi: 10.4081/ejtm.2015.4836. eCollection 2015 Jan 7. Review.

43. Costa A, Rossi E, Scicchitano BM, et al. Neurohypophyseal Hormones: Novel Actors of Striated Muscle Development and Homeostasis. Eur J Transl Myol 2014;24:3790. doi: 10.4081/ejtm.2014.3790. eCollection 2014 Sep 23. Review.

44. Veneziani S, Doria C, Falciati L, Castelli CC, Illic GF. Return to Competition in a Chronic Low Back Pain Runner: Beyond a Therapeutic Exercise Approach, a Case Report. Eur J Transl Myol 2014;24:2221. doi: 10.4081/ejtm.2014. 2221. eCollection 2014 Sep 23.

45. Carraro $U$. Collection of the Abstracts of the 2019Sp PMD: Translational Myology and Mobility Medicine. Eur J Transl Myol 2019;29:8155, in press.

46. Azevedo-Coste $C$, Vergeron $V$, Berkelmans $R$, et al. Comparison of strategies and performance of functional electrical stimulation cycling in spinal cord injury pilots for competition in the first ever CYBATHLON. Eur J Transl Myol 2017;27:251-4.

47. Kern H, Hofer C, Löfler S, et al. Atrophy, ultrastructural disorders, severe atrophy and degeneration of denervated human muscle in SCI and Aging. Implications for their recovery by Functional Electrical Stimulation, updated 2017. Neurol Res 2017;39:660-666. doi: 10.1080/01616412.2017.1314906. Epub 2017 Apr 13.

48. Kern H, Carraro U, Adami N, et al. Home-based functional electrical stimulation rescues permanently denervated muscles in paraplegic patients with complete lower motor neuron lesion. Neurorehabil Neural Repair 2010; 24:709-21.

Received for publication: February 11, 2019 Revision received: February 20, 2019

Accepted for publication: February 21, 2019 